\title{
Pembatalan Akta Notariil Oleh Notaris
}

\author{
Jenifer Maria \\ Magister Kenotariatan, Fakultas Hukum, Universitas Surabaya \\ Email: jenifermaria0208@ hotmail.com
}

\begin{abstract}
Notary is a public official that is inaugurated by a state to give legal and community services regarding civil law. Notary has several authorities, one of which is to make a written evidence in the form of authentic deed / notary deed. An authentic deed has a perfect evidentiary nature. An authentic deed is important in terms of creating a legal certainty, as an authentic deed can not be cancelled arbitrarily because of its nature as a state document. Therefore it is important to have a research regarding the cancellation of a notary deed by notary itself. This research is done by using normative juridical research method, with an approach using acts, regulations, and legal theories.
\end{abstract}

Keywords: cancellation, notary deed, notary

Abstrak. Notaris merupakan pejabat umum yang diangkat oleh negara untuk dapat memberikan pelayanan hukum kepada masyarakat dalam bidang hukum perdata. Ada kewenangankewenangan yang dimiliki oleh Notaris salah satunya adalah membuat alat bukti surat yang berbentuk akta otentik/akta notaris. Akta otentik memiliki kekuatan pembuktian sempurna. Peran Akta otentik sangat penting untuk menciptakan kepastian hukum oleh karenanya tidak dapat dibatalkan dengan sembarangan karena merupakan dokumen negara. Oleh sebab itu penting kiranya dilakukan penelitian mengenai pembatalan akta notarial oleh Notaris. Penelitian ini dilakukan dengan Metode Penelitian Yuridis Normatif, dengan pendekatan masalah melalui peraturan perundang-undangan dan pendekatan teori-teori hukum.

Kata Kunci: Pembatalan, Akta Notariil, Notaris

\section{PENDAHULUAN}

\section{Latar Belakang Umum}

Profesi Notaris sudah lama dikenal, bahkan sejak Indonesia belum merdeka tepatnya sejak abad ke-17. Kedudukan Notaris dalam sistem hukum Indonesia adalah untuk melayani masyarakat dalam bidang hukum perdata, khususnya dalam hal membuat alat bukti untuk suatu perbuatan hukum maupun persitiwa hukum. Notaris dan produknya berupa akta dapat dimaknai sebagai upaya negara untuk mendukung terciptanya kepastian dan perlindungan hukum bagi anggota masyarakat. Senada dengan pernyataan tersebut pengertian Notaris berdasarkan Pasal 1 angka 1 Undang-Undang Nomor 30 Tahun 2004 tentang Jabatan Notaris sebagaimana telah diubah dengan UndangUndang Nomor 2 tahun 2014 tentang Perubahan Atas Undang-Undang Nomor 30 Tahun 2004 tentang Jabatan Notaris (selanjutnya disebut Undang-Undang Jabatan Notaris) adalah pejabat umum yang berwenang untuk membuat akta otentik dan memiliki kewenangan lainnya sebagaimana dimaksud dalam Undang- Undang ini atau berdasarkan undang-undang lainnya.

Secara lebih spesifik kewenangan Notaris diatur lebih lanjut di Pasal 15 Undang-Undang Jabatan Notaris yaitu Notaris berwenang membuat Akta otentik mengenai semua perbuatan, perjanjian, dan penetapan yang diharuskan oleh peraturan perundangundangan dan/atau yang dikehendaki oleh yang berkepentingan untuk dinyatakan dalam Akta otentik, menjamin kepastian tanggal pembuatan Akta, menyimpan Akta, memberikan grosse, salinan dan kutipan Akta, semuanya itu sepanjang pembuatan Akta itu tidak juga ditugaskan atau dikecualikan kepada pejabat lain atau orang lain yang ditetapkan oleh undang- undang. Akta atau 
tulisan tersebut merupakan hasil curahan isi pikiran yang dituangkan dalam bentuk rangkaian huruf berupa tulisan dan akta atau surat ini dapat digunakan sebagai alat bukti serta merupakan salah satu dasar pertimbangan putusan seorang hakim di dalam memutus perkara yang ditangani. Akta/surat sebagai salah satu buktu tertulis yang merupakan suatu penuangan dari hasil pemikiran seseorang atau lebih dari seorang yang dituangkan dalam bentuk gambar, huruf, tulisan dan rangkaiannya berupa kalimat serta mempunyai makna atau arti (Prajitno, 2018).

Perbedaan antara akta otentik dengan akta di bawah tangan berkaitan dengan kepastian hukum yang terletak di kekuatan pembuktiannya. Akta otentik memiliki kekuatan pembuktian sempurna dan mengikat. Akta otentik itu menjadi bukti dari kebenaran seluruh isinya, sampai ada bukti yang menandakan kepalsuan akta itu, sedangkan akta di bawah tangan barulah mempunyai kekuatan bukti, jikalau tanda tangannya diakui atau dianggap sebagai diakui benarnya; adapun tentang tanggalnya akta itu, terhadap pihak ketiga, tidak mempunyai kekuatan sebagai bukti (M (Tresna, 1982).

Dengan demikian dapat dimaknai bahwa Notaris merupakan pejabat yang diberi kewenangan untuk membuat alat bukti berupa surat. Pasal 1867 BW mengatur bahwa pembuktian dengan tulisan dilakukan dengan tulisan-tulisan otentik maupun dengan tulisantulisan di bawah tangan. Akta yang dibuat oleh maupun dihadapan Notaris tergolong sebagai tulisan-tulisan otentik karena memenuhi ketentuan Pasal 1868 BW yaitu bentuknya ditentukan oleh Undang-Undang, dibuat oleh atau dihadapan pegawai-pegawai umum yang berkuasa untuk itu di tempat di mana akta dibuatnya. Pendapat lain dikemukakan oleh Irawan Soerodjo, bahwa ada 3 unsur esensialia agar terpenuhinya suatu syarat akta otentik, yaitu:

1. Dibuat dalam bentuk yang ditentukan oleh Undang-Undang;

2. Dibuat oleh dan dihadapan pejabat umum;

3. Akta tersebut dibuat oleh dan dihadapan pejabat umum yang berwenang untuk itu dan di tempat dimana akta itu dibuat.
Untuk Kekuatan pembuktian akta otentik adalah sempurna, berarti bahwa kebenarannya dianggap benar sepanjang tidak ada pihak lain yang menyangkal kebenaran akta tersebut.

Notaris membuat akta berdasarkan kehendak penghadap, sehingga isi akta yang berupa perbuatan hukum atau pernyataan atas adanya suatu peristiwa hukum murni merupakan kehendak penghadap yang dituangkan dengan bahasa hukum dalam bentuk akta otentik. Notaris hanya bertanggung jawab sebatas awal dan akhir akta, yakni menjamin kebenaran adanya perbuatan hukum para pihak pada tanggal dan jam, serta tempat yang tertera dalam akta, pelaksanaan dari perbuatan hukum yang tertuang di dalam Akta otentik menjadi tanggung jawab penghadap. Dalam rangka mengakomodir kehendak penghadap, Notaris dapat memberikan saran-saran dan mengarahkan perbuatan hukum tersebut dengan berpijak pada aturan hukum yang benar (Adjie, 2011). Ada kalanya pelaksanaan sebuah perbuatan hukum, seperti contohnya sebuah perjanjian mengalami kendala sehingga tidak bisa dipenuhi atau keberadaan akta tersebut menimbulkan kerugian bagi pihak ketiga.

Dalam hal terjadi perselisihan antara para pihak atau dengan pihak ketiga, maka upaya hukum yang dapat diambil adalah dengan mengajukan gugatan ke pengadilan atau membatalkan akta yang dibuat. Untuk upaya hukum yang pertama para pihak dapat mengajukan gugatan perdata dengan dalih wanprestasi (1243 BW) maupun perbuatan melawan hukum (1365 BW). Sedangkan upaya kedua, para pihak dapat bersepakat untuk membatalkan perjanjian tersebut. Pembatalan suatu perjanjian dapat diatur di dalam perjanjian itu sendiri dalam bentuk syarat batal. Namun akan berbeda apabila akta yang dituntut pembatalannya berupa akta pernyataan ataupun akta relaas. Notaris sebagai pihak yang netral seringkali menjadi pihak yang dipersalahkan dengan adanya akta yang dibuat tersebut, padahal akta tersebut ada karena kehendak penghadap sendiri. Notaris dianggap bertanggung jawab dengan adanya akta tersebut dan seringkali dituntut untuk 
membatalkan akta otentik yang telah dibuat olehnya.

Pembatalan suatu akta otentik tidak dapat dilakukan secara serta merta, karena akta otentik merupakan alat bukti yang sempurna untuk menjamin kebenaran adanya suatu perbuatan hukum. Harus dilihat siapa yang berwenang untuk membatalkan akta otentik tersebut. Oleh sebab itu perlu kiranya untuk diteliti lebih lanjut kewenangan Notaris dalam membatalkan akta yang dibuatnya, agar memberikan landasan yang jelas mengenai kewenangan Notaris terutama manakala terjadi sengketa terkait akta yang dituntut pembatalan.

\section{State of The Art}

State of the art penelitian ini diambil dari beberapa contoh penelitian terdahulu sebagai panduan ataupun contoh untuk penelitian yang dilakukan saat ini. Salah satu penelitian berjudul "Tanggung Jawab Notaris/PPAT terhadap Akta yang Dibatalkan oleh Pengadilan" karya Lidya Christina Wardhani dari Magister Kenotariatan Fakultas Hukum Universitas Islam Indonesia pada tahun 2017 yang menjelaskan lebih lanjut mengenai akibat-akibat hukum terhadap Notaris dan Pejabat Pembuat Akta Tanah (PPAT) yang aktanya dibatalkan oleh pengadilan. Penelitian tersebut juga menjelaskan mengenai tanggung jawab hukum dari Notaris dan Pejabat Pembuat Akta Tanah (PPAT) sebagai pihak yang mengkonstantir kehendak dari para penghadap dan menuangkannya ke dalam Akta yang dibatalkan tersebut.

Penelitian berjudul "Tinjauan Yuridis terhadap Pembatalan Akta Notaris" karya Nur Rahmah Surya Ningsih dari Jurusan Ilmu Hukum Fakultas Syariah dan Hukum Universitas Islam Negeri Alauddin Makassar pada tahun 2015 yang menjelaskan mengenai faktor-faktor apa saja yang menyebabkan akta notaris dapat dibatalkan oleh pengadilan dan apa tanggung jawab notaris terhadap akta yang dibatalkan tersebut.

Penelitian penelitian yang berkaitan dengan pembatalan akta notaris / Pejabat Pembuat Akta Tanah (PPAT) di atas masih sebatas mengenai sebab-sebab apa saja yang dapat menyebabkan pembatalan akta notaris dan bagaimana tanggung jawab notaris / Pejabat Pembuat Akta Tanah (PPAT) terhadap akta yang dibatalkan tersebut. Sementara tujuan dari penelitian ini adalah untuk mengetahui apakah notaris berwenang untuk membatalkan akta notaris yang dibuatnya dan bagaimanakah akibat hukumnya.

\section{METODE}

Penelitian ini merupakan penelitian hukum, yaitu penelitian yang bertujuan untuk memecahkan isu hukum yang dihadapi. Isu hukum dalam penelitian ini adalah Kewenangan Notaris dalam membatalkan Akta Otentik yang dibuatnya. Tipe penelitian yang dipergunakan dalam penelitian ini adalah tipe penelitian yuridis normatif, yaitu penelitian yang didasarkan pada norma-norma hukum positif untuk mendapatkan kebenaran yang bersifat koherensi (Marzuki, 2015).

Pendekatan masalah yang dipergunakan adalah pendekatan peraturan perundangundangan (Statute Approach) dan pendekatan konseptual (Conseptual Approach). Pendekatan peraturan perundang-undangan dilakukan dengan cara menelaah undangundang dan peraturan terkait yang mengatur isu hukum yang sedang diteliti, sedangkan pendekatan konseptual dilakukan dengan menganalisa isu hukum berdasarkan teori-teori hukum, doktrin para sarjana, dan putusan pengadilan (yurisprudensi).

Penelitian ini diawali dengan inventarisasi bahan hukum, kemudian dilanjutkan dengan klasifikasi atau penggolongan bahan hukum yang sejenis, dan sistematisasi bahan hukum. Inventarisasi dilakukan melalui studi kepustakaan dan internet. Langkah analisa dilakukan dengan metode deduksi dan dalam melakukan analisa digunakan penafsiran hukum.

\section{HASIL DAN PEMBAHASAN \\ Kewenangan Notaris Sebagai Pejabat Umum}

Notaris (Notary dalam bahasa Inggris) merupakan sebuah profesi yang memiliki peranan penting di dalam lalu lintas hukum, khususnya dalam bidang hukum 
keperdataan. Di dalam konsiderans UndangUndang Jabatan Notaris dijelaskan dasar filosofis keberadaan Notaris. Dasar filosofis pengangkatan Notaris adalah untuk memberikan perlindungan dan jaminan demi tercapainya kepastian hukum (H.S., 2017). Landasan yuridis pengaturan Notaris tertuang dalam berbagai peraturan perundangundangan, namun yang paling spesifik mengatur mengenai jabatan Notaris adalah Undang-Undang Jabatan Notaris) dan Undang-Undang Jabatan Notaris.

Kewenangan Notaris di atur di Pasal 15 ayat 1 Undang-Undang Jabatan notaris yakni

Notaris berwenang membuat Akta otentik mengenai semua perbuatan, perjanjian, dan penetapan yang diharuskan oleh peraturan perundang-undangan dan/atau yang dikehendaki oleh yang berkepentingan untuk dinyatakan dalam Akta otentik, menjamin kepastian tanggal pembuatan Akta, menyimpan Akta, memberikan grosse, salinan dan kutipan Akta, semuanya itu sepanjang pembuatan Akta itu tidak juga ditugaskan atau dikecualikan kepada pejabat lain atau orang lain yang ditetapkan oleh undang- undang.

Dari rumusan pasal tersebut dapat dipahami bahwa pekerjaan seorang Notaris meliputi membuat akta otentik mengenai perbuatan, perjanjian, dan penetapan yang memang diharuskan oleh peraturan perundang-undangan, contohnya di Pasal 7 ayat 1 Undang-Undang Nomor 40 Tahun 2007 tentang Perseroan Terbatas (selanjutnya disebut Undang-Undang PT) pendirian sebuah perseroan terbatas (PT) harus dinyatakan dengan akta Notaris dan perubahan anggaran dasar PT juga harus dinyatakan dalam bentuk akta notaris (Pasal 90 ayat 2 Undang-Undang PT). Perbuatan hukum yang dikehendaki oleh penghadap untuk dituangkan dalam akta contohnya adalah perjanjian yang demi memberikan jaminan kepastian hukum, dibuat dalam bentuk akta otentik. Pengecualian terhadap akta yang dapat dibuat Notaris sepanjang oleh Undang-Undang tidak ditugaskan kepada pejabat lain, contohnya Akta perkawinan tidak dapat dibuat oleh
Notaris karena oleh Undang-Undang Nomor 1 Tahun 1974 tentang Perkawinan (selanjutnya disebut Undang-Undang Perkawinan) telah diamanatkan kepada pejabat catatan sipil, sehingga bukan lagi menjadi tugas Notaris untuk mencatatkan perkawinan. Kewenangan yang dimiliki Notaris adalah kewenangan yang bersifat atributif, karena kewenangan yang melekat padanya lahir dari Undang-Undang. Kewenangan lain Notaris diatur di Pasal 15 ayat 2 Undang-Undang Jabatan Notaris adalah

a. mengesahkan tanda tangan dan menetapkan kepastian tanggal surat di bawah tangan dengan mendaftar dalam buku khusus;

b. membukukan surat di bawah tangan dengan mendaftar dalam buku khusus;

c. membuat kopi dari asli surat di bawah tangan berupa salinan yang memuat uraian sebagaimana ditulis dan digambarkan dalam surat yang bersangkutan;

d. melakukan pengesahan kecocokan fotokopi dengan surat aslinya;

e. memberikan penyuluhan hukum sehubungan dengan pembuatan Akta;

f. membuat Akta yang berkaitan dengan pertanahan; atau

g. membuat Akta risalah lelang.

Berdasarkan sifatnya akta Notaris terbagi menjadi dua yakni akta yang dibuat oleh Notaris (Relaas) dan yang dibuat dihadapan Notaris (Partij). Akta Relaas berisi uraian mengenai kejadian atau perbuatan yang disaksikan sendiri oleh Notaris atas permintaan para pihak untuk dicatatkan dalam bentuk akta otentik. Contoh akta Relaas adalah akta berita acara. Sedangkan Akta Partij merupakan akta yang berisi uraian atau keterangan, pernyataan para pihak yang diceritakan kepada Notaris, untuk dapat dituangkan kedalam bentuk akta otentik. Contoh Akta Partij adalah akta perjanjian. Baik akta Relaas maupun akta Partij harus didasarkan pada kehendak para pihak, isi akta merupakan representasi kehendak para pihak bukan untuk kepentingan Notaris. 
Agar dapat dipergunakan sebagai alat bukti yang sempurna, maka akta Notaris harus memenuhi beberapa persyaratan, yakni:

1. Bentuk akta dibuat dengan berpedoman pada Pasal 38 Undang-Undang Jabatan Notaris yaitu ada awal akta, badan akta, dan penutup akta;

2. Ketentuan mengenai penghadap harus terpenuhi sebagaimana dipersyaratkan oleh Pasal 39 Undang-Undang Jabatan Notaris, yakni :

1. Telah berusia minimal 18 (delapan belas) tahun atau telah menikah

2. Cakap melakukan perbuatan hukum; dan

3. Dikenal oleh Notaris dan pengenalan tersebut dinyatakan secara tegas di dalam Akta Notaris.

3. Dibacakan oleh Notaris dengan dihadiri oleh minimal 2 (dua) orang saksi yang dikenal oleh Notaris (Pasal 40 UndangUndang Jabatan Notaris).

Pelanggaran terhadap persyaratan tersebut mengakibatkan Akta hanya memiliki kekuatan pembuktian dibawah tangan (Pasal 41 Undang-Undang Jabatan Notaris). Degradasi akta otentik menjadi akta bawah tangan hanya berlaku sebatas kekuatannya sebagai alat bukti di pengadilan, namun tidak mengakibatkan eksistensi akta tersebut menjadi batal.

Selain mengenai bentuk akta, dalam menjalankan kewenangannya Notaris juga harus memperhatikan untuk kepentingan siapa akta itu dibuat. Pada dasarnya setiap Notaris memiliki hak yang sama untuk membuat akta bagi siapa saja, namun ada batasan yang harus diperhatikan yakni untuk menjaga objektivitas atau ketidak berpihakan, seorang Notaris dilarang untuk membuat akta untuk orangorang tertentu sebagaimana diuraikan di dalam Pasal 52 Undang-Undang Jabatan Notaris. Orang-orang yang dikecualikan yakni:

1. Diri sendiri;

2. Suami atau istri;

3. Orang lain yang memiliki hubungan kekeluargaan dengan Notaris baik karena perkawinan maupun karena hubungan darah dalam garis keturunan lurus kebawah atau keatas tanpa pembatasan, maupun ke samping sampai derajat ketiga, serta menjadi pihak untuk diri sendiri, maupun dalam suatu kedudukan ataupun dengan perantaraan kuasa.

Selain itu ketentuan mengenai wilayah jabatan juga penting untuk diperhatikan. Akta Notaris yang sah dibuat dan dilangsungkan di dalam wilayah jabatan Notaris. Pasal 19 ayat 2 Undang-Undang Jabatan Notaris mengatur bahwa Notaris memiliki wilayah jabatan meliputi seluruh Propinsi dari tempat kedudukannya. Akta Notaris yang dilangsungkan diluar wilayah jabatan Notaris mengakibatkan akta tersebut menjadi tidak sah.

Notaris juga berwenang membuat akta sepanjang mengenai waktu pembuatan akta tersebut Notaris yang bersangkutan masih dalam keadaan aktif. Aktif artinya Notaris tersebut tidak dalam keadaan cuti atau diberhentikan sementara waktu.

Pelanggaran terhadap ketentuan mengenai wilayah jabatan dan waktu dapat menyebabkan akta otentik yang dibuat oleh Notaris mengalami degradasi dan memiliki kekuatan pembuktian sebagai akta dibawah tangan. Notaris dapat diminta pertanggungjawaban apabila terbukti terdapat kerugian yang timbul akibat degradasi akta yang dibuatnya.

\section{Kewenangan Notaris dalam Membatalkan Akta Otentik yang dibuatnya}

Ada kalanya suatu akta menjadi obyek permasalahan diantara para pihak atau dengan pihak ketiga. Apabila terjadi demikian maka para pihak memiliki 2 (dua) upaya yang dapat ditempuh yakni :

1. Para pihak kembali menghadap ke Notaris untuk membuat akta pembatalan terhadap akta yang dipermasalahkan tersebut. Inisiatif pembatalan murni berasal dari para pihak dan mereka telah sepakat untuk tidak lagi terikat dengan dengan akta otentik yang pernah dibuat.

2. Apabila tidak ada kesepakatan diantara para pihak, atau inisiatif pembatalan datang dari pihak ketiga, maka upaya hukum yang dapat ditempuh adalah dengan mengajukan gugatan ke 
pengadilan dengan mengajukan dalil dan bukti-bukti untuk membatalkan akta tersebut.

Untuk upaya hukum yang pertama, inisiatif pembatalan akta berasal dari kehendak para pihak. Para pihak telah sepakat untuk tidak lagi melanjutkan hubungan hukum sebagaimana dimaksud di dalam akta yang dimintakan pembatalan. Pembatalan semacam ini selaras dengan Putusan Mahkamah Agung (MA) RI Nomor 1420 K/Sip/1978, tanggal 1 Mei 1979. Pada intinya putusan tersebut berisi bahwa Pengadilan tidak berwenang untuk membatalkan akta Notaris, hanya dapat menyatakan akta tersebut tidak mempunyai kekuatan hukum yang mengikat. Hal tersebut berarti eksistensi atau keberadaan akta otentik yang dibuat oleh Notaris masih ada. Para pihak sendiri yang dapat membatalkan akta tersebut. Notaris atas permohonan para pihak dapat membatalkan akta otentik yang telah dibuat sebelumnya dengan membuat akta otentik baru yang mengacu pada akta yang hendak dibatalkan untuk menyatakan bahwa akta tersebut tidak memiliki kekuatan hukum yang mengikat para pihak lagi karena telah terjadi kesepakatan diantara para pihak untuk tidak lagi saling terikat dengan hak dan kewajiban yang ada di dalam akta tersebut.

Upaya hukum kedua adalah dengan mengajukan gugatan ke pengadilan. Upaya ini didasari karena tidak tercapainya kesepakatam diantara para pihak dalam akta untuk membatalkan akta sehingga salah satu dari mereka meminta bantuan pengadilan untuk membatalkan akta otentik sehingga tidak lagi timbul perikatan pada kedua belah pihak. Sebagaimana telah dijelaskan diatas bahwa berdasarkan Putusan Mahkamah Agung (MA) RI Nomor 1420 K/Sip/1978 pengadilan tidak berwenang membatalkan akta otentik yang dibuat oleh Notaris, hanya dapat menyatakan akta tersebut tidak lagi memiliki kekuatan hukum yang mengikat para pihak. Pengadilan dapat menilai berdasarkan argument penggugat dan bukti-bukti yang diajukan untuk mendukung dalilnya tersebut untuk memutuskan apakah suatu akta Notaris memenuhi syarat formil dan materiil. Akta Notaris sebagai produk yang sah dikeluarkan oleh pejabat umum harus diakui kebenarannya, oleh karena itu berlakulah asas praduga sah yang artinya akta Notaris dianggap sah sampai ada yang membuktikan sebaliknya. Tidak terpenuhinya suatu syarat formil dan materill dapat mengakibatkan 3 (tiga) kemungkinan pada akta Notaris :

1. Batal demi hukum.

2. Dapat dibatalkan.

3. Kekuatan pembuktiannya turun menjadi akta dibawah tangan.

Batal demi hukum dan dapat dibatalkan merupakan dua hal yang berbeda namun dipergunakan untuk alasan yang sama yakni tidak tercapainya tujuan dari perikatan. Pengertian batal demi hukum adalah dari awal perbuatan hukum tersebut dianggap tidak ada dan harus dikembalikan dalam kondisi semula sebelum perikatan terjadi. Apabila akta otentik berupa perjanjian maka syarat sebuah akta dapat dinyatakan batal demi hukum adalah karena tidak terpenuhinya syarat obyektif pada Pasal 1320 BW, yakni suatu obyek yang tertentu dan causa yang diperbolehkan.

Sedangkan pengertian dapat dibatalkan adalah Akta tersebut tetap mengikat sepanjang tidak ada pihak yang menuntut agar akta tersebut dibatalkan. Dalam hal akta yang dipermasalahkan berupa perjanjian maka yang dapat dinyatakan sebagai perjanjian yang batal demi hukum adalah karena tidak terpenuhinya syarat subyektif, tekait kewenangan subyeksubyek dalam perjanjian tersebut. Syarat subyektif meliputi kecakapan dan kesepakatan. Kecakapan meliputi usia dewasa, cakap bertindak, dan berwenang untuk melakukan perbuatan hukum. Terkait dengan usia dewasa, yang menjadi acuan adalah usia penghadap sebagaimana diatur di dalam Undang-Undang Jabatan Notaris yakni 18 (delapan belas) tahun. Cakap bertindak berarti orang tersbut tidak ditaruh dibawah pengampuan atau tidak dicabut hak-hak keperdataannya. Sedangkan kewenangan bertindak meliputi untuk siapa perbuatan hukum tersebut dilakukan, apabila untuk orang lain maka harus ada kuasa.

Akta Notaris yang kekuatan pembuktiannya turun menjadi Akta dibawah tangan adalahkarena tidak memenuhi syarat- 
syarat yang ditentukan oleh Undang-Undang. Di dalam Undang-Undang Jabatan Notaris telah diatur secara tegas kondisi-kondisi bilamana akta notaris dinyatakan memiliki kekuatan pembuktian sebagai akta di bawah tangan yakni (Adjie, 2011):

1. Melanggar ketentuan Pasal 16 ayat 1 huruf i;

2. Melanggar ketentuan Pasal 16 ayat 7 dan 8;

3. Melanggar ketentuan Pasal 41 dengan merujuk pada ketentuan Pasal 39 dan 40.

Pembatalan akta otentik yang dibuat oleh Notaris baik oleh para pihak maupun melalui mekanisme gugatan ke pengadilan tidak menyebabkan akta tersebut batal seluruhnya, yang dibatalkan hanya isi aktanya saja, dinyatakan tidak memiliki kekuatan hukum yang mengikat. Notaris tetap wajib menyimpan akta tersebut dalam reportorium dan buku daftar akta sehingga tercipta kronologis yang runtut atas perbuatan hukum tersebut.

\section{KESIMPULAN}

Notaris tidak berwenang membatalkan akta atas prakarsa sendiri apapun kondisinya. Suatu Akta Notaris dibuat atas kehendak para penghadap sehingga inisiatif pembatalan haruslah datang dari para penghadap. Notaris tidak bertanggungjawab atas isi akta, selama dialngsungkan dengan prosedur yang benar. Pembatalan suatu akta otentik oleh penghadap sendiri tidak serta merta menghapus keberadaan akta tersebut, karena akta yang telah dibuat dengan sah merupakan dokumen negara dan harus tetap tercatat dalam buku daftar akta Notaris (reportorium) sehingga mekanismenya adalah dengan membuat akta baru yang berisi pembatalan dengan mengacu pada akta yang hendak dibatalkan.

Pembatalan melalui mekanisme pengadilan timbul karena tidak tercapainya kesepakaran diantara para pihak untuk membatalkan akta. Namun pengadilan juga tidak memiliki kewenangan untuk membatalkan akta otentik, hanya menyatakan akta tersebut tidak memiliki kekuatan hukum yang mengikat. Pembatalan melalui pengadilan hanya dapat dilakukan manakala ada indikasi bahwa akta otentik yang dibuat tidak memenuhi persyaratan sebagaimana diatur di dalam Undang-Undang. Selama akta tersebut dibuat dengan berpedoman pada ketentuan Undang-Undang maka tidak ada celah yang dapat menyatakan akta tersebut batal demi hukum maupun dapat dibatalkan.

\section{SARAN}

Setiap perbuatan hukum yang hendak dilakukan di hadapan Notaris hendaknya dilandasi oleh itikad baik sehingga tidak menimbulkan masalah di kemudian hari. Notaris juga harus senantiasa menjalankan jabatannya dengan penuh kehati-hatian dan patuh pada aturan dengan berpedoman pada kaidah-kaidah pembuatan akta yang ada pada Undang-Undang Jabatan Notaris untuk menghindari masalah hukum dan terutama menjaga martabat dan reputasi jabatan Notaris yang merupakan pejabat umum yang ditunjuk oleh negara untuk melayani masyarakat dalam bidang hukum perdata. Permasalahan mengenai pembatalan akta dapat diantisipasi dengan mencantumkan syarat batal pada akta, dengan syarat batal tersebut apabila ada kondisi-kondisi yang tidak terpenuhi yang dapat menyebabkan akta tersebut batal, maka secara otomatis dan demi hukum akta tersebut batal tanpa adanya upaya pembatalan lagi.

\section{UCAPAN TERIMA KASIH}

Penulis menyampaikan apresiasi yang setinggi-tingginya dan banyak terima kasih kepada para editor dan reviewer dari Jurnal Ilmu Sosial dan Pendidikan (JISIP) yang memberikan kesempatan seluas-luasnya bagi penulis untuk dapat mempublikasikan penelitiannya. Demikian juga kepada Fakultas Hukum Universitas Surabaya yang telah memberikan penulis ruang untuk dapat menuangkan buah pikiran melalui publikasi penelitian ini.

\section{DAFTAR PUSTAKA}

\section{Buku:}

A.A Andi Prayitno. (2018). Seri A
Kewenangan Notaris dan Contoh 
Bentuk Akta (p. 5-6). Surabaya: Perwira Media.

Habib Adjie. (2011). Kebatalan dan Pembatalan Akta Notaris (p. 10, 81). Bandung: Refika Aditama.

H.S., Salim. (2017). Teknik Pembuatan Akta I (p. 35). Depok: Rajawali Pers.

Marzuki, Peter Mahmud. (2015). Penelitian Hukum (p. 23). Jakarta: Prenadamedia Group.

Tresna, Mr. R. (1982). Komentar atas Reglemen Hukum Acara di dalam Pemeriksaan di Muka Pengadilan Negeri atau HIR dihubungkan dengan ketentuan-ketentuan dari Undang-Undang Darurat Nomor 1 Tahun 1951 diubah dengan Undang-Undang Nomor 11 Tahun 1955 (p. 166). Jakarta: Pradnya Paramita.

\section{Dokumen Pemerintah:}

Burgerlijk Wetboek.

Putusan Mahkamah Agung (MA) RI Nomor $1420 \mathrm{~K} / \mathrm{Sip} / 1978$, tanggal 1 Mei 1979.

Undang-Undang Nomor 2 Tahun 2014 Tentang Perubahan Atas UndangUndang Nomor 30 Tahun 2004 tentang Jabatan Notaris.

Undang-Undang Nomor 30 Tahun 2004 Tentang Jabatan Notaris.

Undang-Undang Nomor 40 Tahun 2007 Tentang Perseroan Terbatas. 